\title{
Silurian myodocope ostracods from Poland
}

Vincent Perrier, Ewa Olempska, David J. Siveter, Mark Williams, and Nicolas Legiot Acta Palaeontologica Polonica 64 (2), 2019: 379-397 doi:https://doi.org/10.4202/app.00552.2018

Newly collected material reveals that the Silurian myodocope ostracods from the Holy Cross Mountains, Poland comprise ten species (one new to science) belonging to four families: Bolbozoidae, Entomozoidae, Rhomboentomozoidae, and Cypridinidae. Biostratigraphic control using graptolites indicates that all three Polish outcrops investigated are of about the same chronostratigraphical level: middle Gorstian, lower Ludlow. The new occurrences in Poland extend the known distribution of several species and reinforce data that show many Silurian myodocope species with wide dispersal. Our new observations on the Holy Cross Mountains material confirm that the occurrences of Silurian myodocopes are mostly associated with pelagic animals and with rocks ranging from mudstone, siltstone or shale deposited in open- or deep-shelf marine settings. The cosmopolitan distribution of these ostracods, coupled with their facies and faunal associations, supports the notion of an ostracod (myodocope) ecological shift from benthic to planktonic habitats during the late Wenlock and Ludlow.

Key words: Ostracoda, Myodocopa, Silurian, Ludlow, Poland, Holy Cross Mountains.

Vincent Perrier [vincent.perrier@univ-lyon1.fr] and Nicolas Legiot [nicolas.legiot@etu.univ-lyon1.fr ], Université de Lyon, UCBL, ENSL, CNRS, LGL-TPE, 69622 Villeurbanne, France. Ewa Olempska [olempska@twarda.pan.pl], Institute of Paleobiology, Polish Academy of Sciences, Twarda 51/55, PL 00-818 Warsaw, Poland. David J. Siveter [djs@leicester.ac.uk ] and Mark Williams [mri@leicester.ac.uk], School of Geography, Geology and the Environment, University of Leicester, Leicester LE1 7RH, UK.

This is an open-access article distributed under the terms of the Creative Commons Attribution License (for details please see creativecommons.org), which permits unrestricted use, distribution, and reproduction in any medium, provided the original author and source are credited. 
Farif Full text $(1,222.4 \mathrm{kB})$ 